\title{
T-Lymphocyte Activation Is Correlated With the Presence of Anti-EBV in Patients With Laryngeal Squamous Cell Carcinoma
}

\author{
JANUSZ KLATKA ${ }^{1}$, ANNA HYMOS ${ }^{1}$, ANNA SZKATUŁA-ŁUPINA ${ }^{1}$, EWELINA GRYWALSKA ${ }^{2}$, \\ BARBARA KLATKA ${ }^{1}$, MICHAŁ TERPIŁOWSKI ${ }^{1}$ and ANDRZEJ STEPULAK ${ }^{3}$
}

${ }^{1}$ Department of Otolaryngology and Laryngeal Oncology, Medical University of Lublin, Lublin, Poland;

${ }^{2}$ Department of Clinical Immunology and Immunotherapy, Medical University of Lublin, Lublin, Poland;

${ }^{3}$ Department of Biochemistry and Molecular Biology, Medical University of Lublin, Lublin, Poland

\begin{abstract}
Background/Aim: Chronic viral infection is an important risk factor in the development of cancer. Failure of immune response to clear the oncogenic infection can facilitate cancer progression. The aim of the present study was to analyze early and late activation of T-lymphocytes related to Epstein-Barr virus (EBV) infection by the expression of markers of activation (CD69, CD25) on the surface of $T$ lymphocytes $\left(\mathrm{CD}^{+}, \mathrm{CD}^{+}, \mathrm{CD} 8^{+}\right)$in patients bearing laryngeal cancer according to absencelpresence immunoglobulin $G$ antibodies to EBV nuclear antigen (EBNA1). Materials and Methods: Thirty-three patients with laryngeal squamous cell carcinoma (LC) and 20 volunteers without cancer (control group) were enrolled in the study. Peripheral blood samples were collected from every individual. The markers of activation of T-lymphocytes were determined by flow cytometry, whereas commercial immunoenzymatic assay kits were used for detection of anti-viral capsid antigen (VCA) IgM, anti-VCA IgG, and anti-EBNAl IgG. Results: Increased early activation of $\mathrm{CDS}^{+}$and $C D 4^{+}$T-lymphocytes was found in patients with $L C$. There was a significantly higher proportion of $\mathrm{CD}^{+}$and $C D 8^{+}$T-lymphocytes expressing $C D 69$ antigen in patients with LC compared to the control group. The proportion of $\mathrm{CD}^{+} \mathrm{CD}^{+} 5^{+}$T-lymphocytes in patients with $\mathrm{LC}$ positive for anti-EBNAI IgG and anti-VCA IgM was lower compared to patients without antibodies to VCA IgM. Conclusion: The dysfunction of immune response in larynx cancer patients could be associated with EBV infection.
\end{abstract}

This article is freely accessible online.

Correspondence to: Professor Andrzej Stepulak, Department of Biochemistry and Molecular Biology, Medical University in Lublin, Chodźki 1, 20-093 Lublin, Poland. Tel: +48 81448 6350, Fax: +48 814486350, e-mail: andrzej.stepulak@umlub.pl

Key Words: Laryngeal squamous cell carcinoma, T-lymphocyte activation, antibodies to EBV.
Laryngeal squamous cell carcinoma (LSCC) is one of the most common types of head and neck cancer that exhibits high mortality (1). Despite improvements in surgical and radiotherapeutic techniques, the 5-year overall survival associated with this cancer type remains poor (59.6-66.8\%) (2). Novel treatment approaches for laryngeal cancer (LC) are immunotherapeutic strategies based on the enhancement of the immune system's recognition of tumor antigens and include stimulation of cellular response and vaccination therapies $(3,4)$. Chronic Epstein-Barr virus (EBV) infection is regarded as an important risk factor for the occurrence of tongue and oropharyngeal cancer $(5,6)$ and is etiologically linked with undifferentiated nasopharyngeal carcinoma (7). EBV DNA was identified in $60 \%$ of patients with laryngeal carcinoma (8)

EBV is widespread in the human population, with seropositivity in IgG class antibodies reaching more than 95\% suggesting past infection (9). Primary EBV infection is manifested as acute infectious mononucleosis, however, it more often occurs as asymptomatic disease (10). The presence of EBV stimulates the humoral and cellular immune responses (11). To establish lifelong persistence in memory B-lymphocytes, EBV has evolved efficient strategies to replicate in oropharyngeal epithelial cells and mucosal B-lymphocytes (10). Although epithelial cells and B-lymphocytes are the major targets of EBV, the virus can also infect natural killer cells, follicular dendritic cells and T-lymphocytes (12). The activation of T-lymphocytes is an important immunological process in tumor antigen recognition (13). Depending on the duration of different antigen stimulation, specific activation markers appear on the surface of T-cells. CD69 antigen appears during the early phase of antigen stimulation, whereas CD25 antigen is regarded as a marker of the late phase of activation (14). The initial phase of immune response to tumor antigens, as determined by CD69 expression, is higher in patients with LC than in LC-free patients, whilst no significant changes were observed in the late-phase marker CD25 (13). In the 
present study, we analyzed early and late activation of Tlymphocytes in patients with EBV antibodies: immunoglobulin $\mathrm{M}$ antibodies and immunoglobulin $\mathrm{G}$ antibodies to the viral capsid antigen (anti-VCA IgM and anti-VCA IgG, respectively) and immunoglobulin $\mathrm{G}$ antibodies to $\mathrm{EBV}$ nuclear antigen (anti-EBNA1 IgG).

\section{Patients and Methods}

Study participants. Thirty-three previously non-treated patients with laryngeal squamous cell carcinoma (LC group; aged between 40 and 79 years) and 20 volunteers (control group; aged between 44 and 67 years) without cancer were enrolled in this study at the Department of Otolaryngology and Laryngeal Oncology of the Medical University of Lublin. The patients' characteristics according to TNM staging system (15) are described in detail in Table I. The study was approved by the Local Medical Ethical Committee (KE-0254/70/2015).

Flow-cytometric analysis of T-lymphocytes and the expression of activation markers $\left(C D 69^{+}\right.$and $\left.C D 25^{+}\right)$. Peripheral blood samples were collected into EDTA-containing tubes and subjected immediately to cellular staining with the following mouse antihuman fluorescently labelled antibodies: fluorescein isothiocyanate (FITC)-conjugated CD3, FITC-anti-CD4, phycoerythrin (PE)conjugated anti-CD8, phycoerythrin-cy5 (PE-cy5) anti-CD69, PEcy5anti-CD25, Pe-Cy5-anti-CD3. Appropriate isotype antibodies controls were used for each sample. All the antibodies and isotype controls were purchased from Becton Dickinson, Franklin Lakes, NJ, USA. The cells were stained for $30 \mathrm{~min}$ at $4^{\circ} \mathrm{C}$ in the dark. Then cells were treated with Lysing Solution (Becton Dickinson) for 10 $\min$ at $4^{\circ} \mathrm{C}$ in the dark. After staining, the cells were washed twice with phosphate-buffered saline. Stained cells were then subjected to flow-cytometric analysis using FACSCalibur flow cytometer (Becton Dickinson).

Evaluation of anti-VCA IgM, anti-VCA IgG, anti-EBNAI IgG concentration. A plasma sample was taken from every patient and volunteer and stored at $-80^{\circ} \mathrm{C}$. Detection of anti-VCA IgM, antiVCA IgG, anti-EBNA1 IgG was performed by means of commercial immunoenzymatic assay kits (all with a limit of detection of $10 \mathrm{U} / \mathrm{ml}$; Demeditec, Kiel, Germany) according to the manufacturer's instructions.

Statistical analysis. The experimental data were analyzed by means of Mann-Whitney $U$-test using Statistica 12 software (StatSoft, Tulsa, OK, USA). Differences between the groups at $p<0.05$ was considered statistically significant.

\section{Results}

All patients in the LC group were anti-VCA IgG-positive and, regardless of TNM status, were divided into two main groups according to anti-EBNA1 IgG status. The EBNA1 IgG-positive group was subsequently divided into two additional groups according to whether they were anti-VCA IgM-positive or -negative. The volunteers in the control group were all anti-VCA IgG and anti-EBNA1 IgG-positive.
Early response of $\mathrm{CD}^{+}$T-helper lymphocytes to antigens, as shown by CD69 expression, is increased regardless of EBNAl status in patients with LC. Abnormal lymphocyte turnover with a decrease of $\mathrm{CD}^{+}{ }^{+}$-lymphocytes is a characteristic feature in patients with cancer. An increased proportion of $\mathrm{CD} 4^{+} \mathrm{T}$-lymphocytes is a sign of significantly improved prognosis for patients with cancer (16). In our study, we observed significantly lower proportions of $\mathrm{CD} 3^{+}$ T-lymphocytes $(p<0.001)$ and $\mathrm{CD}^{+} \mathrm{CD}^{+}$T-lymphocytes $(p=0.002)$ in anti-EBNA1 IgG-positive patients compared with the control group. In contrast, in anti-EBNA1 IgGnegative patients, the proportion of $\mathrm{CD}^{+}{ }^{+}$-lymphocytes compared to the control group did not statistically significantly differ. Similarly to the anti-EBNA1-positive group of patients, the proportion of $\mathrm{CD}^{+} \mathrm{CD}^{+}$ T-lymphocytes in the anti-EBNA1-negative LC group was significantly lower compared with controls $(p=0.033)$. Our results demonstrate that the decline of T-helper population is independent of anti-EBNA1 IgG status and is characteristic of patients with LC (Table II).

We observed that the proportions of $\mathrm{CD}^{+} \mathrm{CD}^{+} 9^{+}$ $(p=0.038)$ and $\mathrm{CD} 4^{+} \mathrm{CD} 69^{+}(p=0.026)$ T-lymphocytes in anti-EBNA1 IgG-positive patients were statistically higher than those in controls $(p=0.038)$. Similarly, in anti-EBNA1 IgG-negative patients, the proportion of $\mathrm{CD}^{+}{ }^{+} \mathrm{CD} 69^{+} \mathrm{T}$ lymphocytes was significantly higher in comparison with the control group $(p=0.007)$, showing intense immune response to tumor antigens (Table III).

Both early and late cytotoxic $C D 8^{+}$T-lymphocyte responses were significantly increased in patients with $L C$, regardless of anti-EBNAI IgG status. In the present study, the differences in the proportion of $\mathrm{CD} 8^{+} \mathrm{CD}^{+}$lymphocytes among patients with LC and the control group were not significant, regardless of anti-EBNA1 IgG status (Table II). However, we showed that the proportion of $\mathrm{CD} 8^{+} \mathrm{CD} 69^{+} \mathrm{T}$ lymphocytes in anti-EBNA1 IgG-positive patients with LC was significantly higher than in controls $(p<0.001)$. Similarly, the proportion of $\mathrm{CD} 8^{+} \mathrm{CD} 25^{+} \mathrm{T}$-lymphocytes was significantly higher in both anti-EBNA1 IgG-positive $(p<0.001)$ and -negative patients with LC $(p=0.004)$ compared with the controls (Table III), thereby our results suggest early and late $\mathrm{CD} 8^{+} \mathrm{T}$-lymphocyte activation.

Decrease of late response of $\mathrm{CD} 4^{+} \mathrm{CD} 25^{+}$T-lymphocytes may be associated with the presence of antibodies to VCA IgM in anti-EBNAl IgG-positive patients with $L C$. CD $4{ }^{+} \mathrm{CD} 25^{+} \mathrm{T}$-cells consist of activating and T-regulatory cells (Tregs); Tregs express higher levels of CD25 than do activated T-lymphocytes (17) Our results showed a significantly higher proportion of $\mathrm{CD} 4^{+} \mathrm{CD} 25^{+}$T-lymphocytes in anti-EBNA1 IgG-positive patients with compared with the control group $(p=0.027)$. In contrast, no significant differences between the proportion of 
Table I. Clinicopathological features of patients with laryngeal cancer ( $n=33$; all anti-viral capsid antigen (VCA) IgG-positive).

\begin{tabular}{|c|c|c|c|c|}
\hline \multirow[b]{2}{*}{ Characteristic } & \multicolumn{3}{|c|}{ Anti-EBNA1 IgG-positive $(n=24)$} & \multirow[b]{2}{*}{$\begin{array}{c}\text { Anti-EBNA1 } \\
\text { IgG-negative }(n=9)\end{array}$} \\
\hline & Total & $\begin{array}{c}\text { Anti-VCA } \\
\text { IgM-positive }(\mathrm{n}=7)\end{array}$ & $\begin{array}{c}\text { Anti-VCA } \\
\text { IgM-negative }(\mathrm{n}=17)\end{array}$ & \\
\hline \multicolumn{5}{|l|}{ Age, years } \\
\hline Mean \pm SD & $64.24 \pm 8.23$ & $63.50 \pm 10.95$ & $64.53 \pm 7.33$ & $55.00 \pm 11.33$ \\
\hline \multicolumn{5}{|l|}{ Gender, n (\%) } \\
\hline Male & 24 & 7 & 17 & 9 \\
\hline Female & 0 & 0 & 0 & 0 \\
\hline \multicolumn{5}{|l|}{ T-Stage, n (\%) } \\
\hline 1 & $1(4.2 \%)$ & 0 & $1(5.9 \%)$ & 0 \\
\hline 2 & $2(8.3 \%)$ & $1(14.3 \%)$ & $1(5.9 \%)$ & $1(11.1 \%)$ \\
\hline 3 & $8(33.3 \%)$ & $1(14.3 \%)$ & $7(41.2 \%)$ & $3(33.3 \%)$ \\
\hline 4 & $13(54.2 \%)$ & $5(71.4 \%)$ & $47 \%(8)$ & $5(55.6 \%)$ \\
\hline \multicolumn{5}{|l|}{ N-Stage, n (\%) } \\
\hline 0 & $5(20.8 \%)$ & $2(28.6 \%)$ & $3(17.6 \%)$ & 0 \\
\hline 1 & $7(29.2 \%)$ & $2(28.6 \%)$ & $5(29.4 \%)$ & $2(22.2 \%)$ \\
\hline 2 & $10(41.7 \%)$ & $2(28.6 \%)$ & $8(47.1 \%)$ & $6(66.7 \%)$ \\
\hline 3 & $2(8.3 \%)$ & $1(14.2 \%)$ & $1(5.9 \%)$ & $1(11.1 \%)$ \\
\hline \multicolumn{5}{|l|}{ M-Stage, n (\%) } \\
\hline M0 & 0 & 0 & 0 & 0 \\
\hline M1 & 0 & 0 & 0 & 0 \\
\hline \multicolumn{5}{|l|}{ Grading, n (\%) } \\
\hline 1 & $3(12.5 \%)$ & $1(14.3 \%)$ & $2(11.8 \%)$ & $2(22.2 \%)$ \\
\hline 2 & $75 \%(18)$ & $5(71.4 \%)$ & $13(76.4 \%)$ & $7(77.8 \%)$ \\
\hline 3 & $3(12.5 \%)$ & $1(14.3 \%)$ & $2(11.8 \%)$ & 0 \\
\hline
\end{tabular}

EBNA1: Epstein-Barr nuclear antigen, IgG: immunoglobulin G, IgM immunoglobulin M. *Anti- VCA IgM-positive: n=7; anti-VCA IgM-negative: n=2.

$\mathrm{CD} 4^{+} \mathrm{CD} 25^{+}$T-lymphocytes in anti-EBNA1 IgG-negative patients and the controls were found, meaning that in antiEBNA1 IgG-negative patients, dysfunction of immune response was observed. We also suggest involvement of regulatory response mediated by $\mathrm{CD}^{+}$T-cells with high expression of CD25 antigen in anti-EBNA-IgG-positive patients (Table III). The presence of anti-EBV antibodies (anti-VCA $\operatorname{IgM}^{+}$, antiVCA $\mathrm{IgG}^{+}$, anti-EBNA1 $\mathrm{IgG}^{+}$) in patients indicates recent or recurrent infection (18). Interestingly, the proportion of $\mathrm{CD} 4{ }^{+} \mathrm{CD} 25^{+}$T-lymphocytes in anti-EBNA1 IgG/anti-VCA IgM-positive patients with LC was lower compared to patients without antibodies to VCA IgM: $48.55 \%(29.61 \%-74.61 \%)$ versus $67.69 \%(33.09 \%-80.27 \%)$, respectively $(p=0.040)$, supporting our hypothesis that lower expression of late markers during recent infection or recurrent phase of EBV infection may be associated with dysfunction of immune response.

\section{Discussion}

$\mathrm{CD}^{+}$T-lymphocytes play a pivotal role in maintaining anticancer immune response (19). An increased proportion of these cells in the tumor environment was correlated with more favorable prognosis for patients with head and neck cancer (16). It was also shown that EBV infection is associated with a reduction of the number of $\mathrm{CD}^{+} \mathrm{T}$ lymphocytes in patients with EBV-related cancer (20). Despite the involvement of EBV infection in the development of cancer having been extensively studied (5, $8,9,21-27)$, reports analyzing the initial phase of immune response and lymphocyte activation affected by viral infection are rare. During primary EBV infection, antibodies to VCA IgM are generated and persist from weeks to months. Antibodies to EBNA1 IgG appear later and suggest an ongoing infection. In contrast, infection-induced antibodies to VCA IgG show a lifelong persistence, with different amounts fluctuating over time after EBV infection (28). EBV infection subsequently inhibits the activation of EBV-specific CD4 ${ }^{+}$lymphocytes (29). Thus, the effector cell response does not eliminate $\mathrm{EBV}$ infection, which results in latent infection (30).

Lymphocyte imbalance with a decrease in $\mathrm{CD}^{+}{ }^{+} \mathrm{T}$ lymphocytes was observed in patients with LC (31). Similarly, our results showed significant decrease of $\mathrm{CD}^{+}$ T-lymphocytes in both anti-EBNA1-positive and -negative patients with LC. Additionally, no differences were observed in $\mathrm{CD}^{+} \mathrm{T}$-lymphocytes in these groups. Thereby, our data indicate that the presence of antibodies to EBNA1 IgG is not associated with reduction of $\mathrm{CD}^{+}{ }^{+} \mathrm{T}$-lymphocytes. 
in vivo 33: $2007-2012(2019)$

Table II. Subsets of lymphocytes (\%) in patients with laryngeal cancer (LC) and the control group.

\begin{tabular}{|c|c|c|c|c|c|}
\hline \multirow[t]{2}{*}{ Subsets of lymphocytes } & \multirow[b]{2}{*}{ Control group $(n=20)$} & \multicolumn{4}{|c|}{$\mathrm{LC}(\mathrm{n}=33)$} \\
\hline & & EBNA1 IgG-positive $(n=24)$ & $p$-Value* & EBNA1 IgG-negative $(n=9)$ & $p$-Value* \\
\hline $\mathrm{CD}^{+}$ & $76.49(63.34-83.08)$ & $68.26(51.43-84.20)$ & $<0.001$ & $71.31(45.92-81.68)$ & 0.285 \\
\hline $\mathrm{CD}^{+}{ }^{+} \mathrm{CD} 3^{+}$ & $50.02(36.67-62.12)$ & $39.20(18.40-60.53)$ & 0.002 & $41.04(32.10-55.94)$ & 0.033 \\
\hline $\mathrm{CD}^{+}{ }^{+} \mathrm{CD} 3^{+}$ & $23.79(12.88-47.66)$ & $24.73(10.05-42.00)$ & 0.877 & $25.69(10.46-36.13)$ & 0.789 \\
\hline
\end{tabular}

EBNA1: Epstein-Barr nuclear antigen. Data are median (range). *Versus the control group.

Table III. Percentage of lymphocytes expressing CD69 and CD25 antigens in patients with laryngeal caner (LC) and the control group.

\begin{tabular}{|c|c|c|c|c|c|}
\hline \multirow[b]{2}{*}{ Antigens expressed } & \multirow[b]{2}{*}{ Control group $(n=20)$} & \multicolumn{4}{|c|}{$\mathrm{LC}(\mathrm{n}=33)$} \\
\hline & & EBNA1 IgG-positive $(n=24)$ & $p$-Value* & EBNA1 IgG-negative $(n=9)$ & $p$-Value* \\
\hline $\mathrm{CD}^{+}{ }^{+} \mathrm{CD} 69^{+}$ & $3.13(1.77-6.39)$ & $4.07(1.40-11.14)$ & 0.038 & $8.90(1.72-12.32)$ & 0.182 \\
\hline $\mathrm{CD} 4{ }^{+} \mathrm{CD} 69^{+}$ & $2.91(1.5-7.58)$ & $4.23(0.81-13.84)$ & 0.026 & $8.14(2.00-10.11)$ & 0.007 \\
\hline $\mathrm{CD}^{+}{ }^{+} \mathrm{CD} 69^{+}$ & $0.80(0.29-1.27)$ & $3.68(1.09-8.85)$ & $<0.001$ & $3.7(1.06-10.99)$ & $<0.001$ \\
\hline $\mathrm{CD}^{+}{ }^{+} \mathrm{CD} 25^{+}$ & $30.13(26.05-58.34)$ & $39.83(9.49-61.57)$ & 0.332 & $42.25(11.16-89.93)$ & 0.285 \\
\hline $\mathrm{CD} 4{ }^{+} \mathrm{CD} 25^{+}$ & $45.04(39.82-67.74)$ & $59.43(29.61-80.27)$ & 0.027 & $61.60(41.79-96.69)$ & 0.142 \\
\hline $\mathrm{CD} 8{ }^{+} \mathrm{CD} 25^{+}$ & $1.82(0.55-3.90)$ & $5.80(0.94-80.41)$ & $<0.001$ & $7.02(1.68-85.94)$ & 0.004 \\
\hline
\end{tabular}

EBNA1: Epstein-Barr nuclear antigen. Data are median (range). *Versus the control group.

The activation of T-lymphocytes is an important immunological process in the recognition of tumor antigens. Our data indicate increased early activation of $\mathrm{CD}^{+}$and $\mathrm{CD} 4^{+} \mathrm{T}-$ lymphocytes in patients with LC compared to the control group. Similarly to another report, showing higher expression of CD69 on T-lymphocytes in patients with LC (13), we demonstrated the appropriate increase of molecules of early and late activation of $\mathrm{CD}^{+}$T-lymphocytes (CD69 and CD25), whereas the number of $\mathrm{CD}^{+}$T-lymphocytes was not changed. The reduction of $\mathrm{CD}^{+}$T-lymphocytes and abnormal $\mathrm{CD}^{+}$T-lymphocyte activation were showed in patients with EBV-associated hemophagocytic lymphohistiocytosis patients (32). Lymphocyte activation predicts survival in patients with head and neck cancer. It was suggested that the degree of lymphocyte activation may reflect tumor-infiltrating T-lymphocyte function. The high expression of CD69 was found to impair the prognosis of cancer (33). We tried to see whether the proportion of lymphocytes with CD69 expression was dependent on the presence of antibodies to EBV. However, in our present study, increased early activation of $\mathrm{CD}^{+}$and $\mathrm{CD}^{+}{ }^{+}$T-lymphocytes was not associated with the presence of anti-VCA IgM andanti-EBNA1 IgG. It may, therefore, be hypothesized that exposure to tumor antigens leads to an increase in early activation.

Our results showed a higher proportion of $\mathrm{CD} 4^{+} \mathrm{CD} 25^{+} \mathrm{T}-$ lymphocytes in anti-EBNA1 IgG-positive patients as compared to the control group, suggesting that the increase of the $\mathrm{CD} 25^{+} \mathrm{T}$-lymphocyte population might be associated with the increase of Tregs. Tregs are suspected to contribute to the promotion of viral persistence by inducing immunosuppressive factors (interleukin-10, transforming growth factor) (34), and local accumulation of Tregs facilitates tumor development (35). One study suggested that Tregs can prevent the EBV-specific T-cell response in order to control immunopathological damage manifesting as infectious mononucleosis. The development of symptoms of primary EBV infection (infectious mononucleosis) results in the activation of $\mathrm{CD}^{+} \mathrm{T}-1 \mathrm{ymphocytes}$ due to the diminishing of Tregs (34). We observed no differences between the proportion of $\mathrm{CD} 4{ }^{+} \mathrm{CD} 25^{+}$T-lymphocytes in anti-EBNA1 IgG-negative patients with LC compared to the control group, suggesting dysfunction of immune response. Interestingly, the proportion of $\mathrm{CD} 4^{+} \mathrm{CD} 25^{+} \mathrm{T}$-lymphocytes was significantly lower in anti-EBNA1 IgG-positive patients with antibodies to VCA IgM (recent or recurrent infection) than in those without the latter antibodies. Similar results were reported, showing a decreased number of T-lymphocytes with CD25 expression in patients bearing LC (13). However, we showed that differences in the proportion of $\mathrm{CD} 4^{+} \mathrm{CD} 25^{+}$T-lymphocytes may be associated with exposure to EBV antigens. Our data indicate an increased early activation of T-lymphocytes with reduction of the $\mathrm{CD}_{25} 5^{+}$population during recent or recurrent of $\mathrm{EBV}$ 
infection and suggest that dysfunction of immune response in patients with LC might be associated with EBV infection.

\section{Conflicts of Interest}

The Authors declare no conflicts of interest in regard to this study.

\section{Authors' Contributions}

Methodology, AH, EG; ASŁ; formal analysis: AH, EG, ASŁ, MT; laboratory tests: AH, ASŁ, BK, MT; patient qualification: JK, ASŁ; writing - original draft preparation: JK, AH, AS; funding acquisition: JK.

\section{Acknowledgements}

This study was supported by a Research Grant from the Medical University of Lublin, Lublin, Poland (DS 345). The Authors thank Agnieszka Styczynska for editorial assistance and proofreading.

\section{References}

1 Yang C, Wang S, Yang X, Wang L, Niu L and Liu J: Identification of gene expression models for laryngeal squamous cell carcinoma using co-expression network analysis. Medicine 97(7): e9738. 2018. PMID: 29443735. DOI: 10.1097/MD.0000 000000009738

2 Hsueh C, Tao L, Zhang M, Cao W, Gong H, Zhou J and Zhou $\mathrm{L}$ : The prognostic value of preoperative neutrophils, platelets, lymphocytes, monocytes and calculated ratios in patients with laryngeal squamous cell cancer. Oncotarget 8(36): 60514-60527, 2017. PMID: 28947990. DOI: 10.18632/oncotarget.16234

3 Economopoulou P, Perisanidis C, Giotakis E and Psyrri A: The emerging role of immunotherapy in head and neck squamous cell carcinoma (HNSCC): Anti-tumor immunity and clinical applications. Ann Transl Med 4(9): 173, 2016. PMID: 27275486 DOI: $10.21037 / \mathrm{atm} .2016 .03 .34$

4 De Costa A and Young M: Immunotherapy for head and neck cancer: Advances and deficiencies. Anticancer Drugs 22(7): 674 681, 2011. PMID: 21037467. DOI: 10.1097/CAD. 0b013e3 $28340 \mathrm{fd} 18$

5 Drop B, Strycharz-Dudziak M, Kliszczewska E and Polz-Dacewicz M: Coinfection with Epstein-Barr Virus (EBV), human papilloma virus (HPV) and polyoma BK virus (BKPYV) in laryngeal, oropharyngeal and oral cavity cancer. Int J Mol 18(12): pii: E2752, 2017. PMID: 29257122. DOI: $10.3390 /$ ijms 18122752

6 Fołtyn S, Strycharz-Dudziak M, Drop B, Boguszewska A and Polz-Dacewicz M: Serum EBV antibodies and LMP-1 in Polish patients with oropharyngeal and laryngeal cancer. Infect Agent Cancer 12: Article 31, 2017. PMID: 28572837. DOI: 10.1186/ s13027-017-0141-x

7 Tsang C, Deng W, Yip Y, Zeng M, Lo K and Tsao S: EpsteinBarr virus infection and persistence in nasopharyngeal epithelial cells. Chin J Cancer 33(11): 549-555, 2014. PMID: 25223910. DOI: $10.5732 / \mathrm{cjc} .014 .10169$

8 Polz-Gruszka D, Stec A, Dworzański J and Polz-Dacewicz M: EBV, HSV, CMV and HPV in laryngeal and oropharyngeal carcinoma in Polish patients. Anticancer Res 35(3): 1657-1661, 2015. PMID: 25750324.
9 Muderris T, Rota S, Muderris T, Inal E and Fidan I: Does Epstein-Barr virus infection have an influence on the development of laryngeal carcinoma? Detection of EBV by realtime polymerase chain reaction in tumour tissues of patients with laryngeal carcinoma. Braz J Otorhinolaryngol 79(4): 418-423, 2013. PMID: 23929139. DOI: 10.5935/1808-8694.20130075

10 Guerreiro M, Na I-K, Letsch A, Haase D, Bauer S, Meisel C, Roemhild A, Reinke P, Volk HD and Scheibenbogen C: Human peripheral blood and bone marrow Epstein-Barr virus-specific T-cell repertoire in latent infection reveals distinct memory Tcell subsets. Eur J Immunol 40(6): 1566-1576, 2010. PMID: 20232341. DOI: 10.1002/eji.200940000

11 Rowe $\mathrm{M}$ and Zuo J: Immune responses to Epstein-Barr virus: Molecular interactions in the virus evasion of $\mathrm{CD}^{+} \mathrm{T}$-cell immunity. Microbes Infect 12(3): 173-181, 2010. PMID: 20004735. DOI: 10.1016/j.micinf.2009.12.001

12 Ansari M, Singh V, Dutta S, Veettil M, Dutta D, Chikoti L, Lu J, Everly D and Chandran B: Constitutive interferon-inducible protein 16-inflammasome activation during Epstein-Barr virus latency I, II, and III in B and epithelial cells. J Virol 87(15): 86068623, 2013. PMID: 23720728. DOI: 10.1128/JVI.00805-13

13 Starska K, Głowacka E, Kulig A, Lewy-Trenda I, Bryś M and Lewkowicz P: The role of tumor cells in the modification of Tlymphocyte activity - the expression of the early CD69+, CD71+ and the late $\mathrm{CD} 25^{+}, \mathrm{CD} 26^{+}, \mathrm{HLA} / \mathrm{DR}^{+}$activation markers on $\mathrm{CD}^{+}$and $\mathrm{CD}^{+}{ }^{+} \mathrm{T}$-cells in squamous cell laryngeal carcinoma. Part I. Folia Histochem Cytobiol 49(4): 579-592, 2011. PMID: 22252752. DOI: 10.5603/FHC.2011.0081

14 Reddy M, Eirikis E, Davis C, Davis HM and Prabhakar U: Comparative analysis of lymphocyte activation marker expression and cytokine secretion profile in stimulated human peripheral blood mononuclear cell cultures: An in vitro model to monitor cellular immune function. J Immunol Methods 293(1-2): 127-142, 2004. PMID: 15541283. DOI: 10.1016/j.jim.2004.07.006

15 Amin MB, Edge S, Greene F, Byrd D, Brookland R, Washington M, Gershenwald J, Compton C, Hess K, Sullivan D, Jessup J, Brierley J, Gaspar L, Schilsky R, Balch Ch, Winchester D, Asare E, Madera M, Gress D and Meyer L: AJCC Cancer Staging Manual Eighth Edition. Springer International Publishing, 2017.

16 Hoesli R, Birkeland AC, Rosko A, Issa M, Chow K, Michmerhuizen N, Mann J, Chinn S, Shuman A, Prince M, Wolf G, Bradford C, McHugh J, Brenner J and Spector M: Proportion of CD4 and CD8 tumor-infiltrating lymphocytes predicts survival in persistent/recurrent laryngeal squamous cell carcinoma. Oral Oncol 77: 83-89, 2018. PMID: 29362129. DOI: 10.1016/j.oraloncology.2017.12.003

17 Kuniyasu Y, Takahashi T, Itoh M, Shimizu J, Toda G and Sakaguchi S: Naturally anergic and suppressive CD25+CD4+ Tcells as a functionally and phenotypically distinct immunoregulatory T-cell subpopulation. Int Immunol 12(8): 1145-1155, 2000. PMID: 10917889. DOI:10.1093/intimm/12.8.1145

18 De Paschale $M$ and Clerici P: Serological diagnosis of EpsteinBarr virus infection: Problems and solutions. World J Virol 1(1): 31-43, 2012. PMID: 24175209. DOI: 10.5501/wjv.v1.i1.31

19 Badoual C, Hans S, Rodriguez J, Peyrard S, Klein C, Agueznay N, Mosseri V, Laccourreye O, Bruneval P, Fridman W, Brasnu D and Eric Tartour E: Prognostic value of tumor-infiltrating CD4 ${ }^{+}$T-cell subpopulations in head and neck cancers. Clin Cancer Res 12(2): 465-472, 2006. DOI: 10.1158/10780432.CCR-05-1886 
20 Pavlovic A, Durdov MG, Capkun V, Pitesa JJ and Sakic MB: Classical Hodgkin lymphoma with positive Epstein-Barr virus status is associated with more FOXP3 regulatory T-cells. Med Sci Monit 22: 2340-2346, 2016. PMID: 27377121. DOI: 10.12659/MSM.896629

21 Chan KCA, Woo J, King A, Zee B, Lam W, Chan S, Chu S, Mak C, Tse I, Leung S, Chan G, Hui E, Ma B, Chiu R, Leung S, van Hasselt A, Chan A and Lo Y: Analysis of plasma Epstein-Barr virus DNA to screen for nasopharyngeal cancer. N Engl J Med 377(6): 513-522, 2017. PMID: 28792880. DOI: 10.1056/NEJ Moa1701717

22 Nogueira C, Mota M, Gradiz R, Cipriano M, Caramelo F, Cruz H, Alarcão A, Castro e Sousa F, Oliveira F, Martinho F, Pereira J, Figueiredo $P$ and Leitão M: Prevalence and characteristics of Epstein-Barr virus-associated gastric carcinomas in Portugal. Infect Agent Cancer 12: Article number: 41, 2017. PMID: 28814970. DOI: 10.1186/s13027-017-0151-8

23 Ingerslev K, Høgdall E, Skovrider-Ruminski W, Henrichsen Schnack T, Lidang M, Høgdall C and Blaakaer J: The prevalence of EBV and CMV DNA in epithelial ovarian cancer. Infect Agents Cancer 14(1): 7, 2019. PMID: 30858874. DOI: 10.1186/ s13027-019-0223-Z

24 Moghoofei M, Mostafaei S, Nesaei A, Etemadi A, Sadri Nahand J, Mirzaei H, Rashidi B, Babaei F and Khodabandehlou N: Epstein-Barr virus and thyroid cancer: The role of viral expressed proteins. J Cell Physiol 234(4): 3790-3799, 2019. PMID: 30362517. DOI: $10.1002 /$ jcp. 27144

25 Kheir F, Zhao M, Strong M, Yu Y, Nanbo A, Flemington E, Morris G, Reiss K, Li L and Lin Z: Detection of Epstein-Barr virus infection in non-small cell lung cancer. Cancers 11(6): 759, 2019. DOI: $10.3390 /$ cancers 11060759

26 Zhou H, Tan S, Li H and Lin X: Expression and significance of EBV, ARID1A and PIK3CA in gastric carcinoma. Mol Med Rep 19(3): 2125-2136, 2019. DOI: $10.3892 / \mathrm{mmr} .2019 .9886$

27 Straathof K, Bollard CM, Popat U, Huls M, Lopez T, Morriss M, Gresik M, Gee A, Russell H, Brenner M, Rooney C and Heslop H: Treatment of nasopharyngeal carcinoma with EpsteinBarr virus-specific T-lymphocytes. Blood 105(5): 1898-1904, 2005. PMID: 15542583. DOI: 10.1182/blood-2004-07-2975

28 Straus S, Cohen J, Tosato G and Meier J: NIH conference. EpsteinBarr virus infections: Biology, pathogenesis, and management. Ann Intern Med 118(1): 45-58, 1993. DOI: 10.7326/0003-4819-118-1199301010-00009
29 Juno J, van Bockel D, Kent S, Kelleher A, Zaunders J and Munier C: Cytotoxic CD4 T-cells-friend or foe during viral infection? Front Immunol 8: 19, 2017. PMID: 28167943. DOI: 10.3389/fimmu.2017.00019

30 Eligio P, Delia R and Valeria G: EBV Chronic infections. Mediterr J Hematol Infect Dis 2(1): e2010022, 2010. PMID: 21415952. DOI: 10.4084/MJHID.2010.022

31 Kuss I, Hathaway B, Ferris RL, Gooding W and Whiteside TL: Decreased absolute counts of T-lymphocyte subsets and their relation to disease in squamous cell carcinoma of the head and neck. Clin Cancer Res 10(11): 3755-3762, 2004. DOI: 10.1158/ 1078-0432.CCR-04-0054

32 Yang C, Zhu X, Zhang T and Ye Q: EBV-HLH children with reductions in $\mathrm{CD}^{+}{ }^{+} \mathrm{T}$ cells and excessive activation of $\mathrm{CD}^{+} \mathrm{T}-$ cells. Pediatr Res 82(6): 952-957, 2017. PMID: 28738028. DOI: $10.1038 /$ pr.2017.178

33 Jørgen Aarstad H, Heimdal J-H, Klementsen B, Olofsson J and Ulvestad E: Presence of activated T lymphocytes in peripheral blood of head and neck squamous cell carcinoma patients predicts impaired prognosis. Acta Oto-Laryngologica 126(12): 1326-1333, 2006. DOI: 10.1080/00016480600702092

34 Wingate P, McAulay K, Anthony I and Crawford D: Regulatory T-cell activity in primary and persistent Epstein-Barr virus infection. J Med Virol 81(5): 870-877, 2009. PMID: 19319950. DOI: $10.1002 / j m v .21445$

35 Gourzones C, Barjon C and Busson P: Host-tumor interactions in nasopharyngeal carcinomas. Semin Cancer Biol 22(2): 127-136, 2012. PMID: 22249142. DOI: 10.1016/j.semcancer.2012.01.002
Received July 12, 2019

Revised July 25, 2019

Accepted July 30, 2019 